\title{
KEPELBAGAIAN DEFINISI DAN PENGGUNAAN SENJATA MENURUT PERSPEKTIF UNDANG- UNDANG DI MALAYSIA
}

\author{
Nor Anita Abdullah \\ School of Law, College of Law, Government and International \\ Studies, Universiti Utara Malaysia \\ noranita@uum.edu.my
}

Received: 30 January 2018 Accepted: 20 October 2018 Published Online: 24 December 2018

\begin{abstract}
ABSTRAK
Pistol, senjata api, pisau, grenad, peluru berpandu, rifel adalah antara bentuk senjata fizikal yang mungkin dikenali orang ramai. Meskipun begitu, perkembangan dalam bidang sains dan teknologi serta pertumbuhan yang luar biasa dalam pembangunan manusia telah membawa kepada kemajuan pengetahuan yang meluas dan lebih baik dalam kalangan pakar untuk menghasilkan senjata moden yang lebih berkesan pada masa akan datang. Pada masa kini, senjata fizikal tidak lagi dieksploitasi untuk mengakibatkan kemusnahan dan kerosakan. Sebaliknya, bahan kimia, biologi, radiologi dan letupan nuklear (CBRNE) digunakan untuk tujuan mewujudkan ketakutan yang maksimum, kematian dan kemusnahan orang ramai dan masyarakat. Pada masa yang sama, persepsi orang ramai terhadap senjata juga akan berubah sekiranya mereka memiliki pengetahuan tentang pelbagai senjata dan cara-cara penggunaannya. Oleh itu, artikel ini bertujuan mendefinisikan senjata yang berbentuk konvensional dan bukan konvensional melalui cara penggunaannya dengan merujuk kepada statut-statut yang relevan dan sedia ada di Malaysia. Terdapat juga usaha untuk membincangkan berbagai-bagai jenis senjata melalui kepelbagaian penggunaannya bagi setiap jenis senjata.
\end{abstract}

Kata kunci: Senjata konvensional, Senjata bukan konvensional, Senjata pemusnah besar-besaran. 


\section{ABSTRACT}

Pistols, guns, firearms, knives, grenades, missiles, rifles are among some of the physical weapons most people may be familiar with. Despite this, advances in science and technology and the remarkable growth in human development have led to an extensive and improved understanding among experts to produce more effective modern weapons in the future. Nowadays, physical weapons are no longer being exploited to inflict destruction and damage. Instead chemical, biological, radiological and nuclear explosions (CBRNE) are used with the intention of creating maximum fear, death and destruction to the masses and society. At the same time, people's perception of weapons will also change if they have knowledge of the variety of weapons and their uses. Therefore, this article intends to define conventional and non-conventional weapons by means of their uses with reference to relevant and existing statutes in Malaysia. There is also an attempt to discuss the various types of weapons by looking into the variety of use for each type.

Keywords: Conventional weapon, Non-conventional weapon, Weapon of mass destruction.

\section{PENGENALAN}

Senjata merupakan satu alat yang digunakan dan boleh mendatangkan kecederaan dan kemudaratan kepada orang lain. Senjata juga digunakan untuk pelbagai tujuan demi mencapai matlamat tertentu. Pistol, senapang, pisau, parang, peluru berpandu, bom dan banyak lagi jenis senjata fizikal yang diketahui umum berupaya mengundang bahaya sekiranya digunakan sama ada secara sengaja atau tidak senjata. Bahaya akibat daripada sesuatu senjata bukan sahaja bergantung kepada cara penggunaannya tetapi juga bergantung kepada pengguna yang menggunakan senjata tersebut.

Dalam konteks perundangan di Malaysia, beberapa akta tertentu menjelaskan secara terperinci perihal senjata dan penggunaannya seperti Akta Senjata 1960, Akta Konvensyen Senjata Kimia 2005, Akta Bahan-bahan Kakisan dan Letupan dan Senjata Berbahaya 1958, Akta Perdagangan Strategik 2010 dan Akta Senjata Api 
(Penalti Lebih Berat) 1971. Selain daripada memberi definisi senjata atau seumpama dengannya, kesalahan menggunakan, memiliki secara sengaja atau tidak sengaja mana-mana senjata dijelaskan secara terperinci di bawah peruntukan akta-akta tersebut.

Kemajuan dalam bidang sains dan teknologi yang semakin membangun di kebanyakan negara di dunia serta pertumbuhan pemikiran yang luar biasa dalam kalangan manusia dengan ciptaan inovasi terkini terutamanya dalam bidang pembuatan senjata menjadi penyebab kepada kewujudan senjata yang semakin pelbagai pada masa kini. Senjata fizikal yang dikenali pada zaman dahulu seperti pisau, pistol dan sebagainya sudah tidak lagi digunakan seperti biasa untuk tujuan mendatangkan kecederaan, kemusnahan dan kematian pada masa sekarang. Terkini, penggunaan bahan kimia, bahan biologi, dan nuklear diolah dan dijadikan sebagai senjata juga mampu mencetuskan ancaman berbahaya sebagaimana penggunaan senjata fizikal. Kesan penggunaan senjata ini lebih berbahaya jika dibandingkan dengan senjata moden walaupun daripada bentuk fizikalnya lebih sofistikated dan berteknologi tinggi. Penggunaan senjata moden seperti ini merupakan senjata yang dikenali sebagai senjata pemusnah besar-besaran walaupun penggunaan senjata ini terhad dari segi jumlahnya. Penggunaannya mungkin amat sedikit berbanding dengan penggunaan senjata yang lebih berbentuk fizikal, namun sekiranya digunakan oleh seseorang, kesannya amat besar kepada masyarakat.

Contoh yang boleh dilihat adalah berdasarkan peristiwa yang tercetus di Amerika Syarikat pada 11 September 2001 yang turut menjadi penyebab apabila Malaysia mengambil langkah yang lebih berwaspada terutamanya dengan ancaman keganasan melalui penggunaan senjata biologi. Ini terbukti dengan tindakan yang diambil melalui pindaan ke atas Kanun Keseksaan yang bertujuan menangani ancaman sedemikian melalui peruntukan Seksyen 130B (2) (a). Merujuk subseksyen (3) (d) seksyen ini menerangkan tentang keganasan yang wujud dalam bentuk perbuatan atau ugutan yang mewujudkan risiko yang serius kepada kesihatan atau pada keselamatan awam atau sebilangan orang awam. Subseksyen (3) (g) (iii) pula menjelaskan bahawa tindakan pengganas juga wujud apabila pengganas menggunakan sesuatu yang “...melibatkan pembebasan ke dalam persekitaran alam atau mana-mana bahagian 
persekitaran alam atau mengedar atau mendedahkan orang awam atau mana-mana bahagian orang awam kepada mana-mana mikrobial atau agen biologi atau toksin". ${ }^{1}$

Jika dilihat dari aspek keganasan itu sendiri, maksudnya berubahubah mengikut peredaran zaman. Pada peringkat awal keganasan itu boleh digambarkan sebagai penderhakaan, kekejaman, kezaliman, keganasan. ${ }^{2}$ Di samping itu, perang juga boleh dianggap sebagai satu bentuk keganasan yang telah lama dipraktikkan untuk tujuan keadilan. Jika dilihat dalam konteks perundangan di Malaysia, kesalahan berkaitan keganasan boleh dirujuk kepada Kanun Keseksaan (Bab VIA). Keganasan berpunca daripada tindakan yang terhasil daripada entiti pengganas ${ }^{3}$ atau kumpulan pengganas ${ }^{4}$ yang menjalankan apa-apa tindakan pengganasan ${ }^{5}$. Entiti atau kumpulan ini digerakkan oleh pengganas. Menurut Kanun Keseksaan, pengganas didefinisikan sebagai mana-mana orang yang melakukan atau cuba melakukan apa-apa perbuatan ganas atau menyertai atau memudahkan mana-mana perbuatan ganas. ${ }^{6}$

Manakala menurut Akta Keselamatan Dalam Negeri 1960 (Akta 82) yang telah dimansuhkan oleh Kerajaan Malaysia pada tahun 2011

1 Baljit Singh Sidhu, (2007), 'Potential impact of the changes in the Malaysian Penal Code', Malayan Law Journal Article, Vol. 2 xcvii, hlm 6.

2 Shad Saleem Faruqi, Islam, International Law and the War Against Terrorism, University Publication Centre (UPENA) UiTM, Shah Alam, 2006, hlm 102.

3 Seksyen 130B mendefinisikan 'entiti pengganas' sebagai mana-mana entiti yang dimilik atau dikawal oleh mana-mana pengganas atau kumpulan pengganas dan termasuk persatuan entiti sedemikian.

4 Seksyen 130B mendefinisikan 'kumpulan pengganas' sebagai salah satu aktivitinya dan tujuan untuk melakukan atau membantu dalam perlakuan, tindakan pengganas.

5 Seksyen 130B menerangkan bagi tujuan bab ini, 'tindakan pengganas' bermaksud suatu perbuatan atau tindakan ugutan di dalam atau di luar Malaysia di mana - (a) perbuatan atau ugutan jatuh di bawah subseksyen (3) dan tidak jatuh di bawah subseksyen (4) - (b) perbuatan itu dilakukan atau ugutan itu dibuat dengan niat untuk melanjutkan suatu perjuangan politik, agama atau ideologi - (c) perbuatan atau ugutan berniat atau yang boleh semunasabahnya dianggap sebagai berniat - (i) menakutkan orang awam atau menakutkan sebahagian daripada orang awam - (ii) mempengaruhi atau memaksa Kerajaan Malaysia atau kerajaan mana-mana negeri di Malaysia, mana-mana kerajaan lain, atau mana-mana organisasi antarabangsa untuk membuat atau menahan daripada melakukan apa-apa perbuatan.

6 Seksyen 130B Kanun Keseksaan. 
pernah memberi maksud "pengganas" sebagai mana-mana orang yang bertindak dengan;

“(a) menggunakan senjata api, bahan letupan atau amunisi bertindak dengan cara yang memudaratkan keselamatan awam atau penyenggaraan ketenteraman awam atau mengapikan keganasan atau mengesyorkan keingkaran undang-undang atau mana-mana perintah yang sah;

(b) membawa atau ada dalam miliknya atau di bawah kawalannya apa-apa senjata api, amunisi atau bahan letupan tanpa kuasa yang sah baginya; dan

(c) menuntut, memungut atau menerima apa-apa bekalan untuk digunakan oleh mana-mana orang yang bercadang hendak atau yang hampir bertindak atau baru-baru ini telah bertindak dengan cara yang memudaratkan keselamatan awam atau penyenggaraan ketenteraman awam". ${ }^{8}$

Oleh hal yang demikian, kebimbangan terhadap keganasan dan pengganas itu selari dengan penggunaan pelbagai jenis senjata selari dengan perubahan drastik pembuatan senjata di seluruh dunia terutamanya apabila melibatkan pengganas tidak boleh dinafikan. ${ }^{9}$ Pengganas dan penggunaan senjata sangat sinonim. Memandangkan ancaman pengganas adalah tidak mustahil, tidak menentu dan tidak dapat dikenal pasti, maka penggunaan senjata sebegini oleh para pengganas merupakan satu mimpi ngeri bagi masyarakat awam yang akan menerima kesan dan akibat daripada penggunaan tersebut. ${ }^{10}$ Sekumpulan kecil individu sudah mampu menyebabkan kerosakan dan kemusnahan secara besar-besaran dan mewujudkan rasa takut dan panik dalam kalangan orang awam melalui penggunaan apa jenis senjata, di mana-mana dan pada bila-bila masa sahaja. Setiap jenis senjata berbahaya merupakan ancaman memandangkan ia direka khusus untuk sesuatu tujuan tersebut dan pada masa yang sama dapat mencapai matlamat penghasilan senjata itu sendiri. ${ }^{11}$

Seksyen 2 Akta Keselamatan Dalam Negeri 1960 (Akta 82).

Seksyen 2 Akta Keselamatan Dalam Negeri 1960 (Akta 82).

9 Beck, C. J., \& Miner, E. "Who Gets Designated a Terrorist and Why?" Social Forces, vol. 91, no. 3, 2013, pp. 837-872. JSTOR, JSTOR, www.jstor.org/ stable/23361123.

10 Marina Abdul Majid \& Nor Anita Abdullah (2015), An Ethical Code of Conduct for the Non-Proliferation of Biological Agent Among Malaysian Businesses, 2015 International Symposium on Technology Management and Emerging Technologies (ISTMET), August 25-27, Langkawi Kedah, Malaysia.

11 Nor Anita Abdullah \& Rohani Abdul Rahim (2012), 'Weapons Variety: Legal and Public Health Perspectives', Proceedings of the 4th International Conference 


\section{Kepelbagaian Jenis Senjata}

Terdapat pelbagai jenis senjata yang ada bermula daripada peringkat yang paling mudah digunakan kepada yang paling kompleks penggunaannya dan memerlukan kepada pengetahuan, persediaan dan latihan.

Secara umumnya, senjata terbahagi kepada dua bahagian iaitu senjata konvensional dan senjata bukan konvensional (moden).

\section{Senjata konvensional}

Istilah senjata konvensional secara amnya merujuk penggunaan senjata yang tidak melibatkan senjata pemusnah besar-besaran seperti senjata nuklear, kimia dan biologi. Senjata konvensional biasanya melibatkan penggunaan senjata kecil dan ringan seperti pisau, pistol, senapang, bom, peluru, roket, peluru berpandu dan senjata kelompok.

\section{Senjata bukan konvensional}

Senjata bukan konvensional merupakan jenis senjata yang moden dan kebiasaannya merujuk kepada penggunaan senjata yang melibatkan senjata pemusnah besar-besaran. Merujuk terma senjata pemusnah besar-besaran itu sendiri jelas menunjukkan akibat hasil penggunaannya adalah amat besar. Terdapat pelbagai definisi yang diberikan dalam konteks senjata pemusnah besar-besaran. Namun, hanya beberapa definisi sahaja yang memberi penjelasan yang merangkumi aspek tertentu terutamanya yang melibatkan pemusnahan secara besar-besaran.

Berdasarkan takrifan sedia ada, beberapa gambaran yang menjelaskan tentang penggunaan senjata pemusnah besar-besaran dinyatakan sebagai 'mampu menghasilkan kemusnahan yang amat dahsyat,' 'memberi kesan kerosakan kepada harta benda' dan 'memberi kesan kerosakan kepada infrastruktur'. ${ }^{12}$

on International Studies 2012 Managing National and Regional Transformation \& Its Global Challenges, organized by the School of International Studies, Universiti Utara Malaysia at Hotel Impiana, KLCC.

12 W. Seth Carus, Defining Weapons of Mass Destruction, National Defense University, Washington, 2012, hlm 36-37. 
Namun, kesan yang dinyatakan tersebut juga boleh didapati daripada penggunaan senjata konvensional memandangkan hasil akibat penggunaan senjata konvensional juga mampu menyebabkan kerosakan yang melibatkan harta benda dan infrastruktur. Oleh sebab itu, Pertubuhan Bangsa-bangsa Bersatu yakni United Nations (UN) mengusulkan satu formulasi cadangan definisi senjata pemusnah besar-besaran,

'...senjata atom sebagai bahan letupan, senjata bahan radioaktif, bahan kimia yang boleh membawa maut dan senjata biologi, dan apa-apa senjata yang boleh digunakan pada masa akan datang yang mempunyai ciri-ciri sebagai senjata pemusnah besar-besaran' ${ }^{13}$

Definisi ini diluluskan dalam Perhimpunan Agung Pertubuhan Bangsa-bangsa Bersatu (UN) pada tahun 1946 sebagai resolusi pertama istilah senjata pemusnah besar-besaran.

Menurut perspektif Amerika Syarikat pula, sebagai tambahan kepada definisi tersebut, terma 'amorphous' dimasukkan sebagai menunjukkan bahawa melalui penggunaan senjata pemusnah besar-besaran, apa-apa sahaja yang diingini pasti akan berhasil termasuklah mengakibatkan pemusnahan secara besar-besaran demi mencapai sasaran masing-masing. Rusia pula lebih menitikberatkan penggunaan senjata yang boleh menghasilkan kecederaan berat sebagai senjata pemusnah besar-besaran. Ia termasuk penggunaan bahan kimia, bakteriologi dan nuklear. Bagi negara Soviet pula, senjata pemusnah besar-besaran ditakrif sebagai 'melibatkan penggunaan senjata biologi dan nuklear.' Penggunaan nuklear dan senjata biologi sudah dianggap berupaya menghasilkan kemusnahan secara besar-besaran mengikut konteks senjata pemusnah besarbesaran.

Memandangkan terdapat pelbagai definisi senjata pemusnah besarbesaran yang sedia ada dan kesemuanya adalah tidak jelas dari aspek maksud dan definisinya, terdapat juga beberapa definisi lain yang turut memberi gambaran senjata pemusnah besar-besaran iaitu 'apaapa senjata atau peranti, atau apa-apa yang berupaya, menyebabkan

13 W. Seth Carus, Defining Weapons of Mass Destruction, National Defense University, Washington, 2012, hlm 5-6. 
kematian atau kecederaan badan yang serius terhadap sebilangan besar manusia melalui pembebasan toksik, atau bahan kimia beracun, atau organisma penyakit, atau radiasi atau radioaktif' ${ }^{14}$ Pihak Pengurusan Strategik Amerika Syarikat pula menerangkan senjata pemusnah besar-besaran sebagai meliputi "penggunaan bahan kimia, biologi, radiologi, atau senjata nuklear...'. Definisi ini merangkumi penggunaan senjata yang melibatkan bahan kimia (chemical), biologi (biological), radiologi (radiological) dan nuklear (nuclear) atau dikenali juga sebagai CBRN iaitu penggunaan senjata yang memenuhi kriteria senjata pemusnah besar-besaran itu sendiri.

\section{Jenis Senjata Pemusnah Besar-Besaran}

Terdapat tiga jenis perjanjian perundangan yang dimeterai pada peringkat antarabangsa yang melibatkan penggunaan senjata pemusnah besar-besaran. Perjanjian tersebut berasaskan penggunaan nuklear, biologi dan kimia sebagai senjata pemusnahan besarbesaran. Instrumen perundangan antarabangsa yang mengurus serta mengawal penggunaan tiga bahan utama tersebut ialah Nuclear Non-Proliferation Treaty 1968, Biological Weapons Convention 1972 dan Chemical Weapons Convention 1993.

Rentetan daripada tiga bahan utama sebagai asas kepada terciptanya senjata pemusnah besar-besaran ini, terdapat beberapa penggunaan medium berbahaya kepada kehidupan manusia sekiranya disalah guna oleh mana-mana pihak sama ada secara sengaja atau tidak sengaja. Medium tersebut ialah bahan kimia (chemical material), bahan biologi (biological material), bahan radiologi (radiological material), bahan nuklear (nuclear material), dan bahan letupan (explosive material). Kesemua bahan berbahaya ini dikenali sebagai CBRNE (chemical, biological, radiological, nuclear, and explosive materials) yang dianggap sebagai agen yang berupaya dan berpotensi untuk diolah semula sebagai senjata berbahaya oleh pihak pengganas atau mana-mana pihak secara individu yang mempunyai niat jahat untuk mendatangkan kemudaratan kepada kehidupan manusia. ${ }^{15},{ }^{16}$

14 Seksyen 1403, Defense against Weapons of Mass Destruction Act 1996 (Public Law 104-201).

15 Horowitz, Michael C. and Narang, Neil. "Poor Man's Atomic Bomb? Exploring the Relationship between 'Weapons of Mass Destruction." The Journal of Conflict Resolution, vol. 58, no. 3, 2014, pp. 509-535., www.jstor. org/stable/24545650.

16 Martin, Benjamin E. "Weapons of Mass Destruction: Nuclear Terrorism and Nuclear Proliferation." Counter Terrorist Trends and Analyses, vol. 8, no. 2, 2016, pp. 17-23. JSTOR, JSTOR, www.jstor.org/stable/26369587. 
Senjatabiologibolehmelakukankemusnahan besardandikategorikan sebagai senjata bukan konvensional. Terdapat pelbagai definisi yang diberikan terhadap senjata pemusnah besar-besaran. Senjata tersebut digambarkan sebagai 'mampu menghasilkan kemusnahan yang amat dahsyat,' 'memberikan kesan kerosakan kepada harta benda dan infrastruktur'. ${ }^{17}$ Kesan yang sama boleh dilihat daripada penggunaan senjata konvensional. Disebabkan itu, Pertubuhan Bangsa-Bangsa Bersatu (UN) mencadangkan satu definisi 'senjata pemusnah besarbesaran' iaitu '... senjata atom sebagai bahan letupan, senjata bahan radioaktif, bahan kimia yang boleh membawa maut dan senjata biologi, dan apa-apa senjata untuk kegunaan pada masa akan datang yang mempunyai ciri-ciri sebagai senjata pemusnah besar-besaran.' Definisi ini diluluskan dalam Perhimpunan Agung Pertubuhan Bangsa-bangsa Bersatu (UN) pada tahun 1946 sebagai resolusi pertama istilah senjata pemusnah besar-besaran. ${ }^{18}$

\section{a) Senjata kimia}

Senjata kimia boleh dihasilkan melalui gas, cecair dan semburan. Terdapat empat jenis bahan kimia berbahaya yang boleh digunakan sebagai senjata kimia iaitu, klorin, phosgene, hydrogen cyanide dan gas mustard. Klorin atau phosgene merupakan bahan kimia toksik industri yang amat mudah diperoleh dan tidak memerlukan kepada kepakaran yang tinggi untuk menggunakan dan mencipta senjata kimia dengan bahan tersebut. Peristiwa Aum Shinrikyo di Jepun membuktikan bahawa bahan kimia melalui gas sarin memberi kesan penggunaan senjata kimia di luar jangkaan manusia ketika itu. ${ }^{19}$ Selain itu, penggunaan senjata kimia juga telah lama digunakan sejak Perang Dunia Pertama dan berlanjutan sehingga Perang Dunia Kedua dan Perang Dingin..$^{20}$ Namun, penggunaan, pengeluaran dan pemindahan senjata kimia pada peringkat antarabangsa kini dipantau oleh Chemical Weapons Convention (CWC) yang bertujuan menghalang negara ahli daripada menyalahgunakan bahan kimia sebagai senjata.

17 W. Seth Carus, Defining Weapons of Mass Destruction, National Defense University, Washington, 2012, hlm 36-37.

18 W. Seth Carus, Defining Weapons of Mass Destruction, hlm 5-6.

19 Steve Bowman, (2002), 'Weapons of Mass Destruction: The Terrorist Threat', CRS Report for Congress, The Library of Congress, hlm 4.

20 Richard Falkenrath, 'Confronting Nuclear, Biological and Chemical Terrorism', in Alan O'Day (ed.), Weapon of Mass Destruction and Terrorism, Ashgate Publishing Limited, USA, 2004, hlm 95. 


\section{b) Senjata nuklear}

Senjata nuklear mampu menghasilkan kemusnahan yang amat dahsyat. ${ }^{21}$ Tindak balas senjata kimia dapat dilihat melalui dua cara iaitu fission dan fusion. Senjata kimia yang bersifat fusion menghasilkan kemusnahan yang paling teruk jika dibandingkan dengan senjata kimia yang bersifat fission tetapi ia memerlukan kepada kepakaran penghasilan yang amat tinggi berserta kos yang amat besar. Senjata kimia bersifat fission pula tidak terlalu kompleks dan impak penggunaannya juga mampu mengakibatkan kematian anggaran 100,000 orang penduduk di dalam satu kawasan bandar. Peristiwa pengeboman di Hiroshima dan Nagasaki ialah contoh apabila senjata kimia bersifat fission digunakan. ${ }^{22}$ Namun, bahan menghasilkan senjata nuklear amat sukar diperoleh, memerlukan kos yang tinggi, kemahiran, dan tempat yang luas dan mudah dikenal pasti menjadi penghalang kepada penghasilannya. Sejarah juga membuktikan bahawa isu sekuriti yang tercetus pada ketika itu disebabkan oleh ancaman senjata nuklear yang dicetuskan di antara Amerika Syarikat dengan Soviet Union. ${ }^{23}$ Penggunaan nuklear sebagai senjata sehingga menyebabkan ancaman sekuriti juga boleh dianggap sebagai senjata untuk tujuan peperangan. ${ }^{24}$

\section{c) Senjata biologi}

Senjata biologi boleh dihasilkan melalui penggunaan agen biologi yang boleh didapati secara semula jadi dan boleh mengakibatkan penyakit berjangkit. Terdapat beberapa jenis agen biologi yang berpotensi digunakan sebagai senjata biologi iaitu smallpox, anthrax dan plague. Di samping itu, wujud juga beberapa jenis agen biologi lain seperti tularemia, botulism dan hemorrhagic fevers (Ebola dan Marburg strains). Terdapat 53 jenis agen biologi lain yang turut

21 Richard A. Falk and David Krieger. 'Nuclear weapons and international law.' Path to Zero. Routledge, 2015. 141-162.

22 Richard Falkenrath, 'Confronting Nuclear, Biological and Chemical Terrorism', in Alan O'Day (ed.), Weapon of Mass Destruction and Terrorism, Ashgate Publishing Limited, USA, 2004, hlm 93.

23 Kaiser, David. 'History: From blackboards to bombs.' Nature News 523.7562 (2015): 523.

24 Nor Anita Abdullah dan Rohani Abdul Rahim (2012), 'Penyakit berjangkit: Isu kesihatan awam dalam aspek sekuriti', Jurnal Kanun, 24 Kanun (2), Disember 2012 . 
dikenal pasti berupaya dijadikan sebagai senjata biologi. ${ }^{25}$ Fakta ini membuktikan bahawa pelbagai jenis penemuan agen berkaitan mampu mencetuskan fenomena perang biologi melalui penggunaan senjata biologi.

Antara tiga jenis senjata pemusnah besar-besaran seperti yang disebutkan, penggunaan senjata nuklear adalah paling rendah berbanding penggunaan senjata biologi dan senjata kimia. ${ }^{26}$ Namun, senjata nuklear mampu menimbulkan tahap ketakutan yang tinggi dalam kalangan manusia sekiranya tercetus. ${ }^{27} \mathrm{Hal}$ ini disebabkan oleh sifat manusia yang beranggapan bahawa penggunaan nuklear adalah lebih dahsyat berbanding penggunaan senjata kimia dan biologi yang mana pada pengetahuan umum, gambaran tentang penggunaan kimia dan biologi sebagai senjata tidak jelas berbanding nuklear yang sering dipaparkan melalui media cetak dan elektronik.

Di samping itu, senjata pemusnah besar-besaran ini juga dianggap sebagai ancaman bersifat teknologi yang boleh digunakan oleh pengganas untuk mencapai matlamat mereka. ${ }^{28}$ Pengganas tidak lagi menggunakan senjata biasa yang bersifat konvensional memandangkan senjata pemusnah besar-besaran terbukti mampu menghasilkan impak yang maksimum.

\section{SENJATA MENURUT PERSPEKTIF UNDANG-UNDANG MALAYSIA}

\section{Definisi senjata konvensional}

Definisi senjata yang bersifat konvensional diperuntukkan dalam Akta Senjata 1960 sebagai:

25 Victoria Sutton dan D. Allan Bromley, (2005), 'Understanding technologies of terror', Technology in Society 2, hlm 272-275.

26 Kyler Ong. "Nuclear Terrorism:Assessing the Threat from North Korea." Counter Terrorist Trends and Analyses, vol. 8, no. 2, 2016, pp. 11-16. JSTOR, JSTOR, www.jstor.org/stable/26369586.

27 Alan O'Day, Weapon of Mass Destruction and Terrorism, Ashgate Publishing Limited, USA, 2004, hlm xiv.

28 Charles L. Mercer, Jr, 'Terrorist, WMD, and the US Army Reserve', in Alan O'Day (ed.), Weapon of Mass Destruction and Terrorism, Ashgate Publishing Limited, USA, 2004, hlm 60. 
Apa-apa jenis senjata maut berlaras yang darinya sesuatu letusan, peluru atau lain-lain bedilan boleh dilepaskan, atau yang boleh disesuaikan untuk melepaskan tembakan mana-mana letusan, peluru atau lain-lain bedilan tersebut, dan apa jua jenis senjata yang direka bentuk atau disesuaikan untuk melepaskan tembakan apa-apa cecair berbahaya, gas, atau lain-lain benda, dan termasuklah sepucuk senapang angin, senapang automatik mana-mana bahagian komponen mana-mana senjata tersebut, dan apa-apa barang tambah kepada senjata-senjata itu yang direka bentuk atau disesuaikan untuk mengecilkan bunyi atau pancaran api yang disebabkan dengan menembak senjata itu. ${ }^{29}$

Walau bagaimanapun, terdapat beberapa definisi lain yang merangkumi pengenalan kepada senjata turut dinyatakan dalam akta ini seperti 'senjata tiruan' yang didefinisikan sebagai:

“apa-apa yang berupa atau dicadangkan untuk memberi sangkaan sebagai suatu senjata sama ada atau tidak melepaskan sesuatu letusan, peluru, bedilan, cecair berbahaya, gas atau lain-lain benda."

Pengenalan definisi ini menjelaskan tentang perihal senjata yang wujud dan berkemungkinan digunakan oleh seseorang dengan niat untuk menggunakannya dengan cara yang salah dan mendatangkan kemudaratan kepada orang lain. Menurut peruntukan yang terkandung dalam Akta Senjata Api (Penalti Lebih Berat) 1971 pula menggunakan istilah 'senjata api ${ }^{30}$ yang membawa maksud;

“apa-apa jenis senjata maut berlaras yang daripadanya sesuatu letusan, peluru atau bedilan lain boleh dilepaskan dengan alat cas letupan dan termasuklah sesuatu bom atau grenad yang mengandungi cas letupan."

Terdahulu, Akta Keselamatan Dalam Negeri 1960 (telah dimansuhkan pada tahun 2011) ada memperuntukkan istilah 'senjata api' pula sebagai;

\footnotetext{
29 Seksyen 2 Akta Senjata 1960.

30 Seksyen 2 Akta Senjata Api (Penalti Lebih Berat) 1971

31 Seksyen 2 Akta Keselamatan Dalam Negeri 1960.
} 
Apa-apa jenis senjata maut berlaras yang daripadanya apa-apa letusan, peluru atau misil lain yang boleh dilepaskan atau yang boleh disesuaikan untuk melepaskan apa-apa letusan, peluru atau misil lain yang sedemikian dan apa-apa senjata daripada apa jua pun perihalan yang direka bentuk atau disesuaikan bagi melepaskan apa-apa cecair, gas atau benda lain yang berbahaya dan termasuklah apa-apa bahagian komponen mana-mana senjata yang disebut terdahulu.

Menurut Akta Bahan-bahan Kakisan dan Letupan dan Senjata Berbahaya 1958 pula, istilah 'senjata berbahaya' meliputi sebarang alat yang boleh digunakan sebagai senjata dalam kesalahan yang mana boleh menyebabkan kecederaan. Dalam akta yang sama juga menyenaraikan beberapa jenis 'senjata berjadual' ${ }^{32}$ antaranya pisau (atau seumpama dengannya), kapak, pedang, keris dan sebagainya yang apabila digunakan boleh mendatangkan bahaya kecederaan dan maut kepada orang lain.

Di samping itu, terdapat istilah lain yang digunakan dalam beberapa peruntukan tersebut yang turut menggambarkan definisi dan penggunaan senjata bersifat konvensional. Antaranya ialah 'amunisi' yang didefinisikan menurut Akta Senjata 1960 sebagai;

Apa-apa jenis senjata maut berlaras yang daripadanya apa-apa letusan, peluru atau misil lain yang boleh dilepaskan atau yang boleh disesuaikan untuk melepaskan apa-apa letusan, peluru atau misil lain yang sedemikian dan apa-apa senjata daripada apa jua pun perihalan yang direka bentuk atau disesuaikan bagi melepaskan apa-apa cecair, gas atau benda lain yang berbahaya dan termasuklah apa-apa bahagian komponen mana-mana senjata yang disebut terdahulu. 33 ,

Menurut Akta Keselamatan Dalam Negeri 1960 yang terdahulu pula mentakrifkannya sebagai:-

\footnotetext{
32 'Senjata berjadual' yang membawa maksud senjata berbahaya seperti mana yang terkandung di dalam Jadual Kedua dalam Akta Bahan-bahan Kakisan dan Senjata Berbahaya 1958.

33 Seksyen 2 Akta Senjata 1960.
} 
bagi mana-mana senjata api sebagaimana yang ditakrifkan kemudian daripada ini dan termasuklah grenad, bom dan misil serupa yang lain sama ada boleh digunakan dengan senjata api sedemikian atau tidak dan apa-apa amunisi yang mengandungi atau direka bentuk atau disesuaikan supaya mengandungi apa-apa cecair, gas atau benda lain yang berbahaya.

Selain itu, istilah lain yang menggambarkan definisi dan penggunaan senjata bersifat konvensional selain amunisi ialah 'letupan', ${ }^{34}$ dan 'bahan-bahan kakisan dan bahan-bahan letupan'35.

Gambaran definisi dan penjelasan yang didapati dalam aktakata tersebut, penggunaan senjata yang dimaksudkan disifatkan sebagai berbahaya jika digunakan dengan niat untuk mendatangkan kemudaratan, kecederaan atau kematian. Penekanan diberi kepada aspek fizikal seperti yang diketahui umum sebagai fungsi senjata iaitu seperti pistol atau senapang yang digunakan untuk membedil, bom atau grenad yang digunakan untuk menghasilkan letupan. Walau bagaimanapun, senjata sebegini amat susah untuk diperoleh memandangkan ia memerlukan kepada lesen dan permit penggunaan. Namun, terdapat juga beberapa peralatan biasa yang mungkin berada dalam milikan orang awam yang boleh didapati dengan mudah seperti pisau, parang, belati dan sebagainya. Namun, jika digunakan dengan cara yang salah, maka undang-undang yang akan menentukan hukuman menurut peruntukan sedia ada.

Penggunaan dan pemilikan senjata yang berbentuk konvensional amat jelas berlaku dalam kes iaitu Public Prosecutor v Mohd Amin bin Mohd Razali \& 28 Ors $^{36}$ apabila kesalahan yang berkaitan senjata melibatkan tindakan melancarkan perang terhadap Yang di-Pertuan Agong (YDPA) pada ketika itu. Menurut kes tersebut, pengganas tersebut terdiri daripada ahli dalam Kumpulan Al-Ma'unah telah melakukan pembelian dan pengumpulan sejenis senjata berbentuk 'pedang' yang dikenali sebagai 'parang kembar' dari sebuah kedai di Central Market, Kuala Lumpur untuk melancarkan serangan perang bagi memenuhi tuntutan misi mereka. Selain itu, pengganas tersebut

Seksyen 2 Akta Letupan 1957.

35 Seksyen 2 Akta Bahan-bahan Kakisan dan Senjata Berbahaya 1958.

36 [2002] 1 AMR 969 
juga memiliki senjata perang yang diperoleh secara rampasan dari beberapa pos tentera seperti di Pos 2, Kem Kuala Rhui, Kem Batalion 304, Kem Grik dan pos di Bukit Jenalik. Berdasarkan kes ini, senjata yang lebih berbentuk konvensional telah diketahui umum tentang kepelbagaian penggunaannya serta mudah untuk diperoleh di manamana sahaja hatta boleh juga diperoleh di kedai biasa sahaja. Ini menunjukkan bahawa senjata jenis ini sangat mudah diperoleh dan digunakan walaupun daripada kalangan orang awam. Akses kepada senjata jenis ini ada di mana-mana. Kebanyakan penggunaan senjata yang berbentuk konvensional ini lebih jelas bentuk dan cara penggunaannya. Niat dan risiko penggunaannya juga lebih jelas kerana bentuknya yang zahir dari segi fizikal yang menampakkan kewujudan dan kegunaan senjata itu sendiri.

\section{Definisi senjata bukan konvensional}

Penerangan yang lebih jelas tentang penggunaan senjata yang bersifat bukan konvensional, yang melibatkan senjata pemusnah besar-besaran boleh didapati melalui peruntukan yang terkandung dalam satu akta baharu iaitu Akta Perdagangan Strategik 2010 (Akta 708). Peruntukan dalam akta ini merangkumi kawalan eksport, pemindahan, transit dan pembrokeran barang strategik, termasuk senjata dan bahan yang berkaitan, dan aktiviti lain yang akan atau boleh memudahkan reka bentuk, pemajuan dan penghasilan senjata pemusnah besar-besaran dan sistem penghantarannya dan untuk membuat peruntukan bagi perkara lain yang berkaitan dengannya, selaras dengan keselamatan negara dan obligasi antarabangsa Malaysia. Akta ini mendefinisikan 'senjata pemusnah besarbesaran' ${ }^{37}$ sebagai:

apa-apa senjata yang direka bentuk untuk membunuh, mencederakan atau menjangkiti orang, haiwan atau tumbuh-tumbuhan menerusi kesan letupan atau penyebaran nuklear atau sifat toksik senjata kimia atau sifat berjangkit atau senjata biologi toksik, dan termasuklah sistem penghantaran yang direka bentuk, disesuaikan atau diniatkan untuk penggunaan senjata sedemikian.

Seksyen 2 Akta Perdagangan Strategik 2010. 
Akta ini juga memberikan definisi senjata-senjata yang berada di bawah jenis senjata pemusnah besar-besar seperti senjata biologi, senjata nuklear dan senjata kimia. Dalam konteks senjata biologi, ${ }^{38}$ definisinya dinyatakan sebagai:
apa-apa mikrobial atau agen biologi lain atau toksin walau apa jua pun asalnya atau kaedah penghasilannya, daripada jenis dan dalam kuantiti yang tidak dapat dijustifikasikan bagi maksud profilaktik, perlindungan atau keamanan yang lain, dan senjata, kelengkapan atau cara penghantaran yang direka untuk menggunakan agen biologi atau toksin bagi maksud permusuhan atau dalam konflik bersenjata.

Definisi senjata kimia ${ }^{39}$ juga boleh didapati melalui peruntukan Seksyen 3 Akta Konvensyen Senjata Kimia 2005 sebagai yang berikut, bersama atau secara berasingan:

(a) bahan kimia toksik, kecuali jika dimaksudkan bagi tujuan yang tidak dilarang di bawah Konvensyen, selagi jenis dan kuantiti adalah selaras dengan tujuan itu;

(b) senjata dan peranti yang direka bentuk secara khusus untuk menyebabkan kematian atau bahaya yang lain melalui sifat toksik atau bahan kimia toksik yang dinyatakan dalam perenggan (a) yang dilepaskan akibat daripada penggunaan senjata dan peranti itu;

(c) apa-apa kelengkapan yang direka bentuk secara khusus untuk digunakan secara langsung berkaitan dengan penggunaan senjata dan peranti yang dinyatakan dalam perenggan (b).

Akta ini merangkumi penerangan secara keseluruhan mengenai penggunaan atau apa-apa yang berkaitan bahan kimia termasuk larangan penghasilan, pengeluaran, pengumpulan stok, penggunaan senjata kimia dan pemusnahannya. Namun, terdapat pengecualian terhadap penggunaan bahan kimia yang dibenarkan sekiranya tidak melibatkan penggunaan melalui penghasilan senjata kimia untuk tujuan seperti:

\footnotetext{
38 Seksyen 2 Akta Perdagangan Strategik 2010.

39 Seksyen 2 Akta Perdagangan Strategik 2010.
} 
(a) perindustrian, pertanian, kajian perubatan, farmaseutikal atau keamanan lain;

(b) perlindungan, iaitu tujuan yang secara langsung berhubung dengan perlindungan terhadap bahan kimia toksik dan dengan perlindungan terhadap senjata kimia;

(c) ketenteraan yang tidak berkaitan penggunaan senjata kimia dan tidak bergantung pada penggunaan sifat toksik bahan kimia sebagai kaedah perang;

(d) penguatkuasaan undang-undang, termasuk kawalan rusuhan di dalam negeri. ${ }^{40}$

Senjata nuklear ${ }^{41}$ pula dinyatakan sebagai:

Apa-apa peranti yang berupaya membebaskan tenaga nuklear dengan cara yang tidak terkawal dan yang mempunyai kelompok ciri yang sesuai untuk penggunaan bagi maksud perang, tetapi tidak termasuk sistem penghantaran jika sistem penghantaran itu boleh diasingkan daripada peranti itu.

Definisi senjata yang bersifat bukan konvensional melibatkan senjata pemusnah besar-besaran seperti senjata biologi, senjata kimia dan senjata nuklear, kesemuanya memberikan impak yang agak besar jika dibandingkan dengan penggunaan senjata yang berbentuk konvensional iaitu lebih zahir dari segi fizikalnya. Sebagai contoh, penggunaan agen biologi sebagai senjata juga boleh dihasilkan jika disalah gunakan oleh mana-mana pihak yang tidak bertanggungjawab. ${ }^{42}$ Berdasarkan perbincangan yang dibahaskan oleh penulis Miriam Cohen $^{43}$, penulis mengambil pendekatan yang dilaksanakan oleh Sidell, Takafuji dan Franz bahawa terdapat empat faktor yang mendorong kepada penggunaan patogen atau agen biologi yang diguna pakai bagi tujuan penghasilan senjata biologi yang boleh disalah gunakan oleh pengganas. Empat faktor tersebut ialah:-

$40 \quad$ Seksyen 3 Akta Konvensyen Senjata Kimia 2005.

41 Seksyen 2 Akta Perdagangan Strategik 2010.

42 Lentzos, Filippa. "Biology's Misuse Potential." Connections, vol. 15, no. 2, 2016, pp. 48-64. JSTOR, JSTOR， www.jstor.org/stable/26326439.

43 Miriam Cohen, 'Bioterrorism in the context of infectious diseases' dalam Felissa R. Lashley dan Jerry D. Durham (pnyt.), Emerging infectious diseases: Trends and issues. Springer Publishing Company, New York, 2007, hlm 420. 
i. Mudah didapati dan dihasilkan dalam kuantiti yang besar,

ii. Sangat berbahaya untuk tujuan penyebab kematian dan kemudaratan hidup manusia,

iii. Dengan penggunaan teknologi yang betul, penyebarannya berlaku dengan mudah, dan

iv. Sangat stabil serta berupaya bertahan dengan hanya memberi kesan kepada kumpulan sasaran.

Berdasarkan faktor-faktor di atas, kesan kemudaratan yang bakal menimpa manusia umumnya adalah sangat besar. Pada masa yang sama, akses kepada agen atau patogen yang dimaksudkan juga sangat mudah diperoleh, hanya dengan sedikit kemahiran yang ada berserta dengan teknologi yang makin canggih sekarang ini, penghasilan senjata yang berbentuk seperti ini adalah tidak mustahil untuk dicipta dan digunakan. Dalam konteks ini, agen biologi memiliki beberapa ciri yang bersifat ganas dan berpotensi menghasilkan beberapa tanda yang sukar dikesan secara spesifik seperti demam atau kemurungan dan tekanan. Penyakit jenis ini tidak menunjukkan simptom tipikal yang jelas sehingga penyakit tersebut menjadi bertambah parah. Faktor-faktor yang dinyatakan oleh Sidell, Takafuji dan Franz ini mendorong kepada penggunaan agen biologi iaitu lokasi agen tersebut mudah didapati dan dihasilkan dalam kuantiti yang besar, sangat berbahaya kerana boleh menyebabkan kematian dan kemudaratan kepada manusia. Sekiranya ia digunakan melalui penggunaan teknologi yang betul dan dihasilkan oleh pakar, maka penyebarannya akan terhasil dengan mudah. Di samping itu, ia sangat stabil serta berupaya bertahan dengan hanya memberikan kesan kepada kumpulan sasaran. ${ }^{44}$

Selain daripada faktor penggunaan agen biologi, penyakit berjangkit yang wujud juga boleh digunakan sebagai medium untuk menghasilkan senjata biologi. Terdapat satu peperangan yang tercetus di Amerika pada tahun 1863 menggunakan medium penyakit berjangkit untuk memerangi musuh pada ketika itu. ${ }^{45}$

44 Marina Abdul Majid, Nor Anita Abdullah, Siti Nurani Mohd Noor dan Chan Kok Gan (2016), 'The Principle of Integration in International Sustainable Development Law (ISDL) with Reference to the Biological Weapons Convention (BWC)', Journal of Sustainability MDPI, 8, 166; doi:10.3390/ su8020166, hlm 5.

45 A. Duncan, A history of biological weapons, black death \& yellow rain, dlm R J Mathews (pnyt), Proceedings of the Biological Weapons Convention Regional Workshop, Asia Pacific Centre for Military Law. Melbourne University Law School, 2005, hlm 17. 
Smallpox merupakan salah satu penyakit berjangkit berisiko tinggi sebagai senjata biologi. Smallpox ditakuti sebagai salah satu penyakit berjangkit yang paling berbahaya pada suatu masa dahulu. Apabila smallpox muncul, ia telah mula digunakan sebagai satu alat senjata biologi dalam konteks penyakit berjangkit ${ }^{46}$ semasa peperangan yang berlaku di Perancis dan India (1754-1767) oleh tentera British di Amerika Utara. ${ }^{47}$ Jadual 1 menunjukkan jenis penyakit berjangkit berisiko yang dijadikan sebagai senjata biologi.

Jadual 1: Daftar penyakit berjangkit berisiko sebagai senjata biologi

\begin{tabular}{ll}
\hline Tahun & Penyakit berjangkit \\
\hline $165-541$ & $\begin{array}{l}\text { Smallpox (Antonine plague, Bubonic plague, Plague } \\
\text { of Justinian) }\end{array}$ \\
1300-1776 & Plague (Black Death), Influenza \\
$1816-1875$ & Cholera, Influenza \\
$1899-1958$ & Influenza (Spanish flu dan Asian flu) \\
$1960-1969$ & Cholera (El Tor), Influenza (Hong Kong flu) \\
$1993-1994$ & Plague \\
$2002-2007$ & AIDS, SARS \\
\hline
\end{tabular}

Sumber: Joseph S. Lombardo dan David L. Buckeridge (pnyt.), Disease Surveillance: A Public Health Informatics Approach ${ }^{48}$

Selain smallpox, tularemia ${ }^{49}$ yang merupakan agen bakteria zoonosis juga digunakan sebagai senjata biologi. Ia mula muncul

46 Pihak tentera mengagihkan selimut yang telah digunakan oleh pesakit yang telah dijangkiti smallpox sebagai cara meletuskan wabak penyakit berjangkit dalam kalangan masyarakat awam. Amerika-India semasa peperangan tersebut.

47 Donald A. Henderson et al, 'Smallpox as a biological weapon: Medical and public health management', (1999), Journal of American Medical Association, Vol. 281, No. 22,(2127 - 2135), hlm 2127-2128. http://www.bt.cdc.gov/agents/ smallpox/smallpoxconsensus.pdf

48 Joseph S. Lombardo dan David L. Buckeridge (pnyt.), Disease Surveillance: A Public Health Informatics Approach, hlm 20

49 Digunakan oleh pihak tentera dalam ujikaji ketenteraan sebagai senjata biologi untuk tujuan peperangan semasa Perang Dunia Kedua. 
pada tahun 1930 dan 1940-an di Eropah, Soviet Union dan Amerika Syarikat. ${ }^{50}$ Ebola juga mempunyai risiko yang sama. Semasa tercetusnya wabak penyakit berjangkit yang menakutkan di negaranegara Afrika pada tahun 1976, tiada terdapat kesungguhan dari negara blok Jepun atau Amerika Syarikat untuk mencipta vaksin virus Ebola. Hal ini kerana fahaman bahawa virus Ebola boleh digunakan sebagai agen bioterorisme. ${ }^{51}$ Oleh sebab itu, vaksin virus Ebola sangat penting bagi menangani serangan penyakit Ebola sebagai persediaan menghadapi kemungkinan penggunaan senjata biologi ini.

Centers for Disease Control and Prevention (CDC) yang beribu pejabat di Atlanta, Georgia, Amerika Syarikat menerangkan bahawa serangan biologi melibatkan kaedah pelepasan virus, bakteria atau kuman yang dilakukan secara sengaja ke sesuatu kawasan. ${ }^{52}$ Kesannya boleh menyebabkan penyakit atau kematian dalam kalangan manusia, binatang dan tumbuhan. Kebiasaannya, agen ini boleh didapati secara semula jadi dari alam. Agen ini boleh disebarkan melalui udara, air dan makanan. Pengganas biasanya akan menggunakan agen tersebut kerana sifatnya yang sukar untuk dikenal pasti pada peringkat awal penggunaannya dan memandangkan ia amat sukar untuk dikesan melainkan beberapa gejala atau tanda yang muncul beberapa lama kemudiannya ${ }^{53}$ dan kebanyakan agen atau virus tersebut boleh menyebabkan penyakit berjangkit.

Perkembangan dalam bidang sains dan teknologi boleh dijadikan sebagai faktor pendorong kepada pengetahuan mengenai beberapa aspek yang melibatkan nuklear, kimia dan agen biologi. Namun, pengetahuan orang awam tentang ancaman nuklear dan kimia lebih luas jika dibandingkan dengan pengetahuan tentang aspek yang

50 David T. Dennis, 'Tularemia as a biological weapon: Medical and public health management', (2001), Journal of American Medical Association, Vol. 285, No. 21, (2763-2774), hlm 2763-2764. http://bioterrorism.slu.edu/bt/news/jama_ tularemia.pdf

51 Cagatay Ustun dan Ozge Ozgurler, 'Ebola: A significant threat as an infectious disease, and as a potential bioterrorism agent', (2005) Turkish Journal of Medical Sciences, 35, (1-4), hlm 1 dan 3.

52 Mishra, Devi Kalyan. "Bioterrorism from a Public Health Perspective." Counter Terrorist Trends and Analyses, vol. 8, no. 2, 2016, pp. 24-30. JSTOR, JSTOR, www.jstor.org/stable/26369588.

53 Maklumat dari Centers for Disease Control and Prevention (CDC), Amerika Syarikat http://www.bt.cdc.gov/agent/agentlist-category.asp\#c 
melibatkan ancaman penggunaan agen biologi. Dalam konteks ini, sejarah membuktikan bahawa kebanyakan peristiwa peperangan berpunca daripada penggunaan bahan kimia dan penggunaan letupan nuklear. Penggunaan tersebut lebih menggerunkan masyarakat awam kerana mereka sedia mempunyai pengetahuan tentang kesan dan akibat penggunaan bahan nuklear. ${ }^{54}$

Selain itu, pencemaran alam sekitar yang berlaku di dunia juga kebanyakannya berpunca daripada penggunaan bahan kimia. Akhbar sering memaparkan isu pencemaran alam yang sering terjadi di darat mahupun di laut yang disebabkan oleh pembuangan sisa bahan kimia. ${ }^{55}$ Sebagai contoh pengusaha kilang berusaha untuk menjimatkan kos dengan mengambil jalan mudah dengan membuang sisa toksik dan kimia ke dalam laut dan sungai. Walaupun menyedari kesan yang akan berlaku akibat perbuatan mereka, namun disebabkan kejahilan dan sikap tidak mengambil berat menyebabkan pemilik industri mengelak daripada mematuhi piawaian keselamatan yang ditetapkan oleh kerajaan dalam konteks pembuangan sisa kimia dan toksin. Dalam konteks penggunaan bahan kimia, peruntukan yang terkandung dalam Akta Konvensyen Senjata Kimia 2005 memberi pengetahuan tentang liabiliti pencemaran alam sekitar berasaskan kimia bukan sahaja kepada alam sekitar itu sendiri malah turut melibatkan aspek hidupan lain di bumi ini.

\section{KESIMPULAN}

Secara kesimpulannya, peruntukan undang-undang perihal senjata yang dinyatakan dalam beberapa akta menjelaskan tentang bahaya dan larangan penggunaan beberapa jenis senjata di Malaysia. Walau sekecil mana bentuk dan fizikal senjata tersebut, jika digunakan dengan cara yang salah dan mendatangkan kemudaratan kepada

54 Nor Anita Abdullah, Ancaman bioterorisme terhadap kesihatan awam dan sekuriti di Malaysia: Satu Kajian Sosio Perundangan, Tesis Ph.D, Universiti Kebangsaan Malaysia, 2013.

55 Mohammad Raduan bin Mohd Ariff, Mohammad Sharir, Ismail Ali, Mazlan Majid, Hanafi Hussin, 'Perkembangan perusahaan perikanan di Semenanjung Malaysia: Isu dan persoalan' (2011) Jati, Vol.6, (265-299)_http://umrefjournal. um.edu.my/filebank/published article/3175/265-299\%20Mohammad\%20 Raduan\%20et.al-PERUSAHAAN\%20PERIKANAN-JATI16,\%202011-\%20 new.pdf 
orang lain, senjata tersebut dianggap berbahaya dan salah dari segi undang-undang. Peristiwa global seperti yang berlaku pada 11 September, 2001 juga mengubah persepsi undang-undang di Malaysia. Malaysia turut mengambil iktibar daripada peristiwa tersebut dengan mengambil pendekatan yang bersifat drastik melalui penambahbaikan terhadap undang-undang sedia ada. Pengenalan tentang senjata pemusnah besar-besaran melalui peruntukan undangundang juga membuktikan bahawa kesedaran dan pengetahuan seseorang terhadap senjata dan tahap kegunaannya amat penting.

Di samping itu juga, kepelbagaian jenis senjata yang ada dan yang dapat dikenal pasti ini juga dapat membantu pihak-pihak tertentu untuk lebih bersedia menghadapi sebarang kemungkinan yang bakal berlaku. Sekiranya dahulu manusia lebih bersifat takut dengan kewujudan dan kemunculan senjata yang lebih zahir dari segi bentuk dan fizikalnya, akan tetapi sekarang ini, rasa takut itu turut berubah jika pengetahuan tentang pengenalan terhadap senjata yang lebih moden dan terkini ini juga wujud dan lebih berisiko sekiranya digunakan oleh seseorang yang tidak bertanggungjawab.

\section{RUJUKAN}

Abdul Majid, M., \& Abdullah, N. A. (2015). An ethical code of conduct for the non-proliferation of biological agents among Malaysian businesses. International Symposium on Technology Management and Emerging Technologies (ISTMET). Ogos. 25-27, Langkawi, Kedah. Malaysia.

Abdul Majid, M., \& Abdullah, N. A., Mohd Noor, S. N. \& Gan, C. K. (2016). The principle of integration in international sustainable development law (isdl) with reference to the biological weapons convention (bwc, Journal of Sustainability MDPI, 8, 166; doi:10.3390/su8020166.

Abdullah, N. A., \& Abdul Rahim, R. (2012). Penyakit berjangkit: Isu kesihatan awam dalam aspek sekuriti, Jurnal Kanun, 24 Kanun (2), Disember.

Abdullah, N. A. \& Abdul Rahim, R. (2012). Weapons variety: Legal and public health perspectives. Proceedings of the 4th International Conference on International Studies Managing National and Regional Transformation \& Its Global Challenges anjuran Pusat Pengajian Pengajian Antarabangsa. Universiti Utara Malaysia. Hotel Impiana. Kuala Lumpur. 
Abdullah, N. A. (2013). Ancaman bioterorisme terhadap kesihatan awam dan sekuriti di Malaysia: Satu kajian sosioperundangan ( Tesis Doktor Falsafah). Universiti Kebangsaan Malaysia.

Akta Bahan Letupan 1957.

Akta Bahan-bahan Kakisan dan Senjata Berbahaya 1958.

Akta Keselamatan Dalam Negeri 1960.

Akta Konvensyen Senjata Kimia 2005.

Akta Perdagangan Strategik 2010.

Akta Senjata 1960 (Akta 206)

Akta Senjata Api (Penalti Lebih Berat) 1971 (Akta 37)

Beck, C. J., \& Miner, E. (2013). Who gets designated a terrorist and why? Social Forces, 91(3). pp. 837-872. JSTOR, JSTOR, www.jstor.org/stable/23361123.

Bowman, S. (2002). Weapon of mass destruction: The terrorist threat. CRS Report for Congress, The Library of Congress.

Carus, W. S. (2012). Defining weapons of mass destruction. National Defense University, Washington.

Centers for Disease Control and Prevention (CDC). Amerika Syarikat. Retrieved from http://www.bt.cdc.gov/agent/ agentlist-category.asp\#c

Cohen, M. (2007). Bioterrorism in the context of infectious diseases. In Lashley, F. R \& Durham, J.D. (Eds.), Emerging infectious diseases: Trends and issues. New York: Springer Publishing Company.

Duncan, A. (2005). A history of biological weapons, black death \& yellow rain, dlm R J Mathews (pnyt), Proceedings of the Biological Weapons Convention Regional Workshop. Asia Pacific Centre for Military Law. Melbourne University Law School.

Defense against Weapons of Mass Destruction Act 1996 (Public Law 104-201).

Dennis, D. T. (2001). Tularemia as a biological weapon: Medical and public health management. Journal of American Medical Association, 285(21) (2763-2774), hlm. 2763 - 2764. http:// bioterrorism.slu.edu/bt/news/jama_tularemia.pdf

Falk, R. A., \& Krieger, D. (2015). Nuclear weapons and international law. Path to Zero. Routledge. 141-162.

Faruqi, S. S. (2006). Islam, international law and the war against terrorism. Shah Alam: University Publication Centre (UPENA) UiTM.

Henderson, D. A. (1999). Smallpox as a biological weapon: Medical and public health management. Journal of American Medical Association, 281(22), 2127-2135. 
Horowitz, M. C., \& Narang, N. (2014). Poor man's atomic bomb? Exploring the relationship between weapons of mass destruction. The Journal of Conflict Resolution, 58(3). 509535.

Kaiser, D. (2015). History: From blackboards to bombs. Nature News. 523.7562. 523.

Lombardo, J. S., \& Buckeridge, D.L. (pnyt.). (2007). Disease surveillance: A public health informatics approach. USA: John Wiley \& Sons.

Martin, B. E. (2016). Weapons of mass destruction: Nuclear terrorism and nuclear proliferation. Counter Terrorist Trends and Analyses, 8(2), 17-23.

Mishra, D. K. (2016). Bioterrorism from a public health perspective. Counter Terrorist Trends and Analyses, 8(2), pp. 24-30.

Mohd Ariff, M. R., Sharir, M., Ali, I., Majid, M., \& Hussin, H. (2011). Perkembangan perusahaan perikanan di Semenanjung Malaysia: Isu dan persoalan. Jati, 6, 265-299.

O'Day, A (pnyt). (2004). Weapons of mass destruction and terrorism. USA: Ashgate Publishing Limited.

Ong, K. (2016). Nuclear terrorism: Assessing the threat from north korea. Counter Terrorist Trends and Analyses, 8(2), 11-16.

Sidhu, B. S. (2007). Potential impact of the changes in the Malaysian Penal Code. Malayan Law Journal Article, 2, xcvii.

Sutton, V., \& Bromley, D. A. (2005). Understanding technologies of terror. Technology in Society xx (xxxx) 1-23.

Ustun, C., \& Ozgurler, O. (2005). Ebola: A significant threat as an infectious disease, and as a potential bioterrorism agent. Turkish Journal of Medical Sciences, 35, 1-4. 